\title{
10
}

\section{Training of Communication Skills in Social Education Students Through an Innovative Experience}

\author{
Virginia Castillo Cidre \\ virginia.castillo@alu.uhu.es \\ Universidad de Huelva
}

Aránzazu Cejudo Cortés

carmen.cejudo@dedu.uhu.es

Orcid: 0000-0002-1165-2237

Universidad de Huelva

\author{
Celia Corchuelo Fernández \\ celia.corchuelo@dedu.uhu.es \\ Orcid: 0000-0003-2938-3079 \\ Universidad de Huelva
}

\begin{abstract}
This chapter presents an innovative experience carried out through a university extension course in the 2016-2017 academic year for Social Education students of the University of Huelva. The main objective has been to facilitate the acquisition of communication skills by the participating students (a total of 21 students). A participative, interactive and expository methodology has been followed between professors and students. The analysis of the data will be made thanks to the results obtained from the satisfaction surveys that the same university uses for this type of workshops that are offered in these calls. The results show a high students motivation in this type of initiatives as well as a very positive attitude on the part of participating professors.
\end{abstract}

Keywords: communication skills, pedagogical innovation, social education

\subsection{Introduction}

The Social Education professional must develop various skills which have been described through the abilities that should be acquiring throughout their training, according to the profession- 
alization document of Asociación Estatal de Educación Social (ASEDES, 2007) and Consejo General de Colegios de Educadores y Educadoras Sociales (CGCEES, 2007). Communication skills are the basis of all other abilities and these are develop throughout the life of the human being, but this does not mean that it is done correctly because we understand that there is a great difference between speaking and communicating correctly what is wanted to be expressed. To communicate is to give form and meaning to a message through a context, a culture and its interpretation of the different signs which are presented in the message, this refers to the non-verbal communication that gives full meaning to the verbal message. This helps to contextualize the message, giving it credibility. In addition, the management of communicative skills facilitates the learning or training of social abilities which are very significant for the professional social education development. It is true that students know what these skills are, but they have lack of training to launch it.

Therefore, it was intended to provide students with tools and specific training in communication and social skills, because they are essential for their day to day as students and future professionals who will live stress and conflict situations, where emotional intelligence and the use of these tools are essential to develop an impeccable work with the diversity of users that will be presented throughout their careers. For this, a workshop was offered in a transversal way to the credits demanded by the study programme, being the main protagonists the students of Social Education in the University of Huelva.

\subsection{Brief review of the university degree in Social Education.}

\section{Antecedents of the degree}

It is necessary to do a historical review of Social Education and the background of the social educator to understand how this degree appeared, due to the necessity caused by social changes, which were produced over the years, and its evolution to the present. For this reason, this professional has been attributed new func- 
tions and therefore the need to develop new professional skills, such as communication skills that will be discussed throughout this project. To understand the progress of these professionals we briefly delve into their history, indicating that in 1947 the Asociación Nacional de Educadores de Jóvenes Inadapados (ANEJI) was founded in France to mitigate various problems arising from industrialization, the Second World War and previously the "paternal houses", causing that young people were introduced in the delinquency owing to the system left them without any protection. This association, from 1948 developed international actions in countries such as Holland, Belgium, Germany, the United States and Canada. As a result of all the above, in 1951 the Asocioación Nacional de Jóvenes Inadaptados (AIEJI) was created, being currently known in Spain as the Asociación Internacional de Educadores Sociales (Allah, 2013).

According to Allah (2013), Germany together with France, were one of the pioneering countries in the configuration of Social Education as a profession. This profession arises in the German country as a result of the political, social and economic changes that arose in the modern stage (Cánovas, 2012). In this way, the first specialized training schools were opened as a response to the disorganisation of human life, marginal neighbourhoods, accumulation of social problems due to industrialization that are accentuated in the post-war period, where the interest group nationally and internationally is that of young people because of the crime that had been generated by social maladjustment (Allah, 2013).

These causes are considered the historical reconstruction of Social Pedagogy, this being the discipline that offers models, strategies and techniques to Social Education so that through this profession they are put into practice. In Riera's words (as quoted in Galiano, 2008, p. 31), by Social Pedagogy it is understood that it is: "The foundation and normalizing science of the educational action specifically oriented to Social Education and the integral social welfare of people, groups or communities, in any context and throughout their life and circumstances". Since the assimilation that Social Pedagogy is the founding science of Social Education, these have always gone hand in hand (Cánovas, 2012).

On the other hand, Spain in the 60s and 70s was immersed in a complicated social situation for diverse reasons such as emigration, a deficient policy that implied a constant social conflict, 
marginal groups, maladjustment, illiteracy, social inequality, juvenile delinquency and a scarce social sensitivity. For these reasons the population mobilized to achieve a democratic reform and achieve the welfare state. These facts encourage the emergence and configuration of the figure of the social educator in the 80s, taking for its development guidelines of the Training Center for Specialized Educators (CFEEB) created in 1969 in Barcelona. These social and political changes arise through the need of the social demand for greater equality to deal with the process of socialization, transmission of norms and educational values to the population and, in this way, achieving the integration of the most disadvantaged sectors of society, minimizing conflicts and social problems (Allah, 2013). In conclusion, according to ANECA (2004, p.114) "the changes that have occurred worldwide, as well as in Europe have been very profound and have affected the labour market, the economy and the lifestyle of citizens. The breadth and depth of these cultural, social and economic transformations are such that, experts believe that knowledge and information have become fundamental factors to manage the differences between people, organizations and countries". It is understood in this way that the changes and social movements in the 20th century led to the development and specialization of professionals who would cover the needs that occurred at the time, such as the professionals of Social Education.

For these reasons, the Ministry of Education and Science officially incorporates the title of social educator after the approval of Royal Decree 1420/1991 of August 30 (BOE of October 10, 1991) by which the Official University Degree is established of Diploma in Social Education, thus providing basic training to these future professionals, acquiring skills and competencies adapted to that professional profile and social contexts where this figure must intervene, being generators of change (ANECA, 2004). Thus, graduates in Social Education in their scientific training are oriented to develop their profession in the field of non-formal education (Galiano, 2008).

Social Education has been based on three different pillars throughout its trajectory, based on socio-educational principles developed in individuals at a social, educational and cultural level. In this way, these aspects are the following: the specialized educator, the sociocultural animator and the adult educator (Cáno- 
vas, 2012). In this way the State Association of Social Education (ASEDES) and Professional Association of Social Educators of Castilla La Mancha (APESCAM) define this profession as a right of citizenship and a profession of pedagogical nature, so the definition established by ASEDES (2004, p. 37) picking up this character is as follows:

... a right of citizenship that is materialized in the recognition of a profession of pedagogical nature, generating educational contexts and mediating and formative actions that are the domain of competence of the social educator and enable: i) The incorporation of the subjects of the education to the diversity of social networks, both as regards the development of sociability and the possibilities of social circulation; ii) cultural and social promotion, understood as an opening to new possibilities for the acquisition of cultural goods that broaden educational, work, leisure and social participation perspectives.

\section{Social Education at the University of Huelva}

Previously, there was no formal academic training to be professionals of Social Education as such. Therefore, the university degree in Social Education is relatively recent, as it has been indicated in the previous section, since it was approved in 1991 in Spanish national territory through Royal Decree 1420/91 of August 30 (BOE of October 10 of 1991), being called the professional: Diploma in Social Education.

On the other hand, the University of Huelva had this degree in its study programme on June 27, 2002 under the compliance of the provisions of article 10.2 of Royal Decree 1497/1987 of November 27 (BOE of August 27, 2002), on its common general guidelines of the study programme of the official character titles and validity in all the national territory with his corresponding modifications, being his first academic course the year 2002/2003 developed in the Faculty of Sciences of the Education.

Meanwhile, the European Space for Higher Education initiated in 1999 the Bologna Declaration to harmonize the universities belonging to the European Union (BOE of October 30, 2007). In this way, the change for the aforementioned Bologna Declaration for the full achievement of its objectives was scheduled for 2010 through the adoption of specific regulations that would guaran- 
tee the new educational construction under a legal framework. In this way, the Organic Law 4/2007, of April 12, modifies the Law 6/2001, of December 21 of Universities to establish the precise bases and thus make a deep modernization of the Spanish University (BOE of October 30, 2007).

In 2010, the BOE number 161 of July 3, 2010, includes Royal Decree $861 / 2010$ of July 2, which modifies Royal Decree $1393 / 2007$ of October 29, by which establishes the organization of official university education. These changes became a great adaptive challenge for Spanish universities towards the transformation of their teaching offer to achieve the new provision. The changes were carried out during the 2010-2011 academic year by implementing the new Bachelor, Master and Doctorate degrees, many of which had already begun to be implemented in some of the Spanish universities.

Then, once we have seen the legal framework of the academic development of the graduates in Social Education, we will focus on the professional competences required of the graduate in Social Education for the optimal development of their profession, because, according to the verified report of the Degree in Social Education (University of Huelva, 2012), this title allows the social educator to develop professionally the scientific knowledge necessary for the understanding, interpretation, analysis and explanation of the theoretical and practical foundations of education in different social spaces and times. It is understood as a social educator according to said verified report (2012, p.19) which is: "the professional who carries out socio-educational interventions with people and in their contexts, in order to achieve full personal and social development, participate in responsible mode in the different social and community spheres, playing with other professionals a role of social and educational intervention ". Within the achievement of this professional profile are specified a series of functions that are well explained both in the verified report (University of Huelva, 2012) that is being treated, as in the "White Book" of Degree in Pedagogy and Social Education (ANECA, 2004), but here only two of them will be cited, since they are the most relevant to justify the purpose of this workshop:

- social, cultural and educational mediation;

- training of socio-educational intervention agents. 
On the other hand, considering the general objectives that support this degree and that justify the need to enhance communication skills and social abilities, we are left with the first objective that appears in the verified report of the Degree in Social Education (University de Huelva, 2012), being this the following:

Qualify students in knowledge, skills, work tools and attitudes that contribute to the development in the implementation and evaluation of educational projects aimed at different subjects and groups, emphasizing communication dynamics, participation, integration and socialization, as well as promotion of a civic coexistence.

After knowing one of the general objectives of the degree, we will focus on the basic skills to be acquired by the students. As can be seen in point B.7 of the verified report (University of Huelva, 2012), this refers to Social Education students must: acquire the skills, abilities and attitudes for socio-educational intervention. Observing the transversal competences, it can be seen that T.1 indicates the use of information and communication technologies in their professional practice (Universidad de Huelva, 2012).

Furthermore, within the list of specific competences which appears in the report (University of Huelva, 2012), we conveniently highlight the following for justifying this workshop:

- E12: know, understand and manage the main concepts, resources and strategies for the development of integral educational actions in community contexts.

- E15: know and understand the concept of sociocultural animation, as well as to manage its techniques for the management of groups, equipment and socio-cultural resources in the development of groups and communities.

- E18: management of audio-visual languages and means of expression and social communication.

- E23: ability to plan, direct and coordinate integral educational projects, learning communities and professional intervention networks.

In the White Book of Degree in Pedagogy and Social Education (ANECA, 2004), the specific competences of disciplinary 
and professional training in its thirteenth acceptation are also detailed, indicating that the social educator must: identify and diagnose the usual factors of family and social crisis and develop a mediation capacity to deal with socio-educational communities and resolve conflicts. To develop this competence according to ANECA (2004), the future professional of Social Education must have in their knowledge the processes of mediation and their practices, in addition to knowledge of techniques and resources for communication as the most important process involved in mediation. To develop this knowledge, you must have the skills to be able to communicate effectively, use different negotiation techniques and have the ability to actively listen and interact. In addition, the attitude that the educator must maintain to achieve all this is to know how to be empathetic, assertive and respectful with the diversity of positions before a conflict, to value diversity as a source of wealth and to have a positive thinking.

As you can see, the Social Education professional requires in his training the ability of certain skills to carry out his work properly. It is true that they are competencies that students believe they have because they know what they are for their academic training, but when they need to put them into practice, they find themselves with a lack of techniques and resources to be assertive and empathetic in the face of a conflict in their daily lives or when they are asked to show a work and take a lower grade because they have not developed the communication skills to express effectively all their knowledge. These are examples of the day to day that happen to these students that because of the nature of their profession they need to manage, for that reason, a workshop was proposed for the promotion of communicative competences destined to those students who considered that they should put them into practice to be a good professional in the future, because as Eduardo Galeano says (as was cited in the Certified Memory of the Bachelor's Degree in Education at the University of Huelva, 2012, p.5): "we are not what we are / otherwise what we do / to change what we are". 


\subsection{Description of the innovative experience called "Taller Comunica-Te"}

Then, it is presented in detail what this workshop consisted in, which was carried out at the University of Huelva in a cross-sectional way to the credits required to obtain the Social Education title, as the authors Gómez, Gómez and Rodríguez (2011) indicate., p.154): "Communication is a basic professional competence at the service of education professionals and as such should be instructed". For this reason, it is important to refer to communication as a fundamental tool for formulating social change, this approach being one of the most recent dependency theories and approaches to communication, taking into account that it is a complex process that depends on the context and of the cultural conditions in which it develops (Pérez, Marion Cataño, \& Franco, 2009). In addition, the study conducted on social skills in students of Social Education of Rojas (2010, p. 235), indicates that "students who have received training in these skills, improve their interpersonal behaviour in social acceptance among their peers / as, assertiveness, repertoire of social skills, self-concept and self-esteem".

The basic principle that sustains communication for social change is dialogue as Paulo Freire indicated (as cited in García, 2011), since there is no communication without dialogue. For this reason, the ultimate goal of communication is to favour social changes to allow people to be better, have a better quality of life and make decisions for themselves, because until now decisions have been made by marginal groups or in social exclusion, but it is necessary to support them so that they have their own voice (Pérez, Marion Cataño, \& Franco, 2009). Hence, the importance of training social educators as agents of change specialized in these skills to successfully exercise their professions, in addition to optimizing interpersonal relationships through training in social skills to promote both personal and professional through active listening processes, dialogues, interviews, persuasion techniques, etc. among many other issues that will be detailed below.

The objectives that were marked for compliance in the "Taller Comunica-Te" are the following: 
- General Objectives:

- To strengthen in communication skills the student of the Degree in Social Education.

- To optimize social skills in the student of the Degree in Social Education.

- Specific Objectives:

- To develop the management of social skills.

- To encourage the ability to speak before a professional future.

- To optimize the self-confidence of the students participating in the workshop.

- To favour the quality in the academic formation of the students of the University of Huelva.

- Transversal Objectives:

- To discover and strengthen the strengths of students regarding communication.

- To manage different communicative situations to adapt to the public.

- To learn schemes and strategies to orally convey information in a complete, attractive and rigorous way.

- To train the participants in the correct use of the different means of support for oral dissemination, applying each one in the appropriate situation.

Regarding the structure, the workshop is divided into six blocks, which cover everything relevant to communication skills and social skills. The blocks were distributed as follows:

- Block 1: Oratory Capacity

- Block 2: Non-verbal components.

- Block 3: Training in social skills.

- Block 4: To speak in public.

- Block 5: To speak in public in different contexts.

- Block 6: Exposition of works + Remember.

This workshop was developed for three weeks and a half, two classes per week of three hours each class. Block 3 will be developed during two consecutive days because the training in social skills required more time for its optimal learning. On the other hand, the students had an hour and a half each day of the work- 
shop to do autonomous work outside of the hours in a non-contact manner. The workshop had a total duration of thirty certifiable hours by the University of Huelva.

\subsection{Some methodological aspects}

In this workshop, an attempt was made to use a participative, interactive and expository methodology, being the participation undoubtedly the leading role:

1. Participative: it was based on previous ideas, experiences and beliefs, attitudes and practices. All the members were involved in the process and the plurality of knowledge present in it was used, enhancing the dynamizing techniques that helped achieve the objectives. It was tried that they were always motivating, mobilizing, playful, creative and democratic, so that they generated the possibility of personal transformation and cultural-social change. The process was addressed with the students being active agents of the same, building and reconstructing their knowledge, skills and abilities. We worked learning by discovering, for this, the students obtained the information in an active and constructive way. It was Carried out two modalities or variants; the 'active-reproductive discovery' or 'active-productive discovery'.

2. Interactive: This methodology highlighted the exchange between the professor or speaker and the student through the debate to delve into a topic. There was an open interaction where the professor or speaker stimulated participation and dialogue with the student. In order to achieve a positive interaction quality criteria were guaranteed for this, the professors or speakers were specialists in the subject, facilitating a climate of relaxation to intervene, fostering a relaxed atmosphere that facilitated participation and guaranteed a positive assessment of the topic occupy In addition, we must bear in mind that the same students were an active part of this teaching-learning process, being mentors of their peers, which means, of other students.

3. Expository: Explanation of the marked contents. The professor or speaker had a leading role and the students were placed at a level of content and information receiver. This is a forma- 
lized and systematic knowledge, which focused on learning about the aspects of the topic addressed that were considered relevant.

This methodology helped the construction of knowledge, the interaction and exchange of opinions and ideas, to collect of experiences, to immerse oneself in reality, to generate reflections on it, to enable students to act as tools to become active subjects of this social transformation. Therefore, the role of the professor in this workshop was to guide and facilitate the learning process, as well as being a motivating and energizing agent throughout the change process. On the other hand, the speakers were responsible for evaluating the work and activities that were carried out in the classroom.

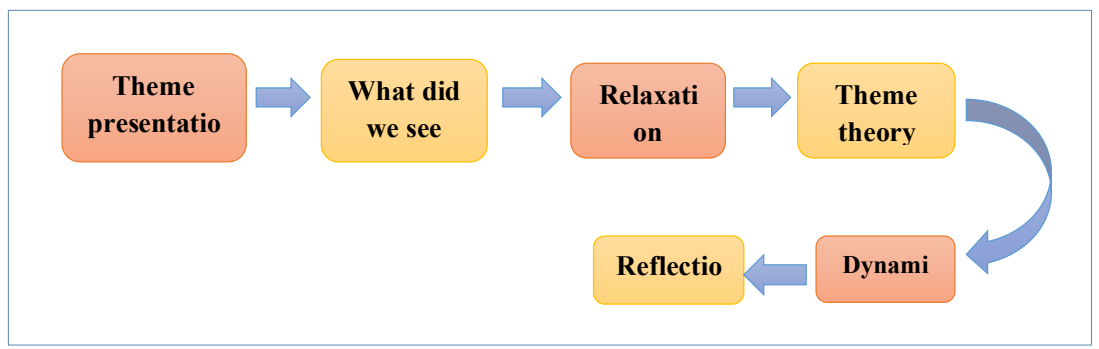

Figure 1. Organization of the different sessions. Source: Own elaboration

\subsection{Some of the results}

Some of the results obtained thanks to the satisfaction surveys of the participants which are relevant to the issue addressed in this chapter are the following:

- Regarding organizational issues of the workshop.

- More than half of the participants think that they agree with the workshop duration, because it is enough for them. However, $14 \%$ say that they disagree and indicate that a greater number of hours would be necessary. In the following graph you can see what is discussed. 


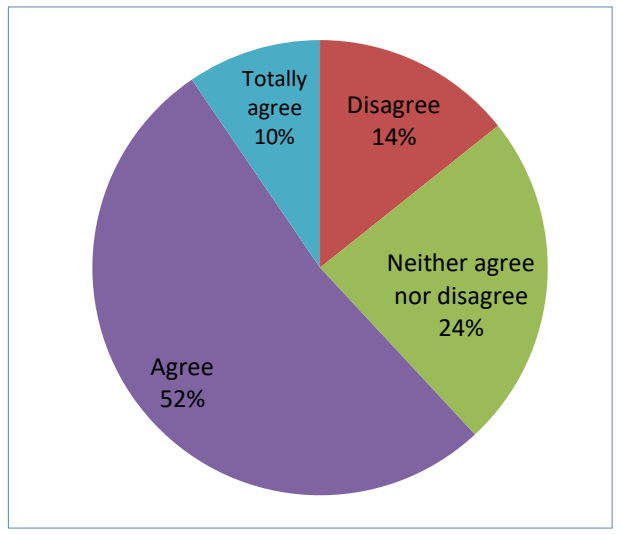

Graph 1. Satisfaction of the participants in relation to the duration of the workshop. Source: Own elaboration

- $57 \%$ of students who have participated think that the schedule in which the workshop has been given is adequate (3 hours, two days a week).

- $62 \%$ of students totally agree that the classroom that has been carried out the workshop is appropriate and 38\% think they agree. This is because the space where it has been developed is a very functional and versatile classroom, with mobile tables and chairs, and a space that is not too big, making it easier to create a cosy and close atmosphere

- Regarding the level of satisfaction of the didactic material delivered and used in the presentations.

- $95 \%$ of the participants agree or totally agree that the materials and resources have been adequate.

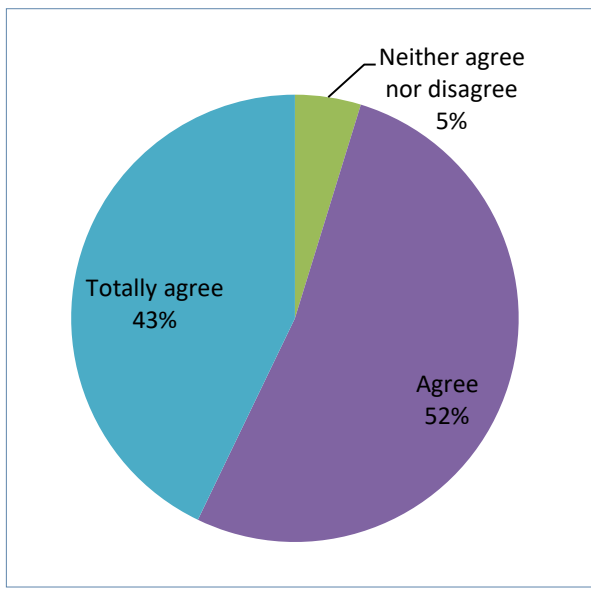

Graph 2. Degree of satisfaction of the materials and resources used. Source: Own elaboration 
- On the other hand, $90 \%$ of students indicate that the presentations used, Power Point, Prezzi, as well as the videos that have been exposed, are adequate.

- All students think that the information provided is up-todate with respect to the topics addressed in the different sessions.

- Level of satisfaction in relation to the methodology used.

- All participants agree or totally agree that they have been given the option to ask all the questions they deem suitable.

- It is also very positive that all students indicate that professors responsible for the workshop, have promoted interaction among all the participants.

- $90 \%$ of students totally agree that the practical dynamics used have been adequate to understand the theory explained.

- $81 \%$ completely agree that professors have clearly explained the contents worked on.

- $71 \%$ express that the training received has been relevant to their needs.

\subsection{Conclusions}

This study has described an innovative university proposal through a workshop that has been developed at the University of Huelva with students of the Social Education degree, in order to improve their communication skills. From the results that have been obtained after carrying out the experience, the following conclusions are reached:

- The degree of satisfaction in relation to the methodology used, the didactic material provided as well as the rest of the organizational issues is quite high, reason why it can be concluded that this type of initiatives is motivating for students.

- The participating professors, after evaluating the sessions that have taken place, determine that the totality of the participating students has positively overcome the challenges that were proposed to them.

- All participants - both students and professors - emphasize that the theme dealt with (communicative competence), the space 
used as well as a low ratio (21 students) have been very important aspects so that the different sessions of the workshop have been productive, dynamic and motivating.

Regarding the limitations, it should be studied how to offer in future workshops, greater numbers of sessions in order to give answers to $14 \%$ of the students who think that the number of hours has been less than their needs.

\section{References}

Ad-Value. (2010). Formación de habilidades comunicativas. Unión Europea. Allah, M. C. (2013). Aproximación histórica a una de las profesiones sociales: la Educación Social, RES Revista de Educación Social, 1-13.

Alzina, R. B. (2003). Educación emocional y competencias básicas para la vida, Revista de Investigación Educativa, 7-43.

ANECA. (2004). Título de Grado en Pedagogía y Educación Social. Bilbao (España): ANECA.

ASEDES \& CGCEES. (2007). Documentos profesionalizadores. Barcelona: ASEDES.

Broglia, A. (2013a). ¿Cómo presentar tu proyecto en público? Available at <http://www.educaixa.com/-/como-presentar-tu-proyecto-en-publico>.

— (2013b). Domina tus miedos. Available at <http://www.educaixa. com/-/domina-tus-miedos>.

Cánovas, J. F. (2012). La realidad sobre la Educación Social: la participación como proceso de profesionalización. Aposta, 52. Available at $<$ http://www.apostadigital.com/revistav3/hemeroteca/jfscanovas.pdfs.

García, M. J., Martín, A. M., Jiménez, M. Á., Ojeda, J. R., \& Cabezas, J. M. (2005). Pautas para comunicación oral y escrita. Melilla: Facultad de Educación y Humanidades. Universidad de Granada.

García, M. R. (2011). Reseña de "Teoría de la comunicación humana" de Paul Watzlawick, Razón y Palabra.

Goméz, Á. H., Gómez, I. A., \& Rodríguez, A. P. (2011). Técnicas de comunicación creativas en el aula: escucha activa, el arte de la pregunta, la gestión de los silencios, Educación y Futuro. Revista de Investigación Aplicada y Experiencias Educativas, 153-177.

Jaca, L. M. \& Díaz, F. J. (2005). Gestión del conflicto, negociación y mediación. Madrid: Ediciones Pirámide. 
Jiménez, J. J., Flores, B. M., Rubio, I. M., \& Delgado, S. H. (2013). Habilidades sociales. Madrid: Mc Graw Hill Education.

Kelly, J. A. (1998 ). Entrenamiento de las habilidades sociales. Bilbao: Desclée de Brouwer .

Marente, E. M. (2014). Habilidades sociales para la intervención socioeducativa: técnica del sandwich. Valencia.

Ministerio de Educación y Ciencia. El arte de hablar: oratoria eficaz. Servicio de Formación del Profesorado.

Muñoz Galiano, I. M (2008). Perfil profesional del educador social con personas mayores. Identificación de competencias (tesis doctoral). Granada: Universidad de Granada.

Pérez, G. J., Marion Cataño, M., \& Franco, F. (2009). Comunicar para el cambio social: una comunicación ética y política. Entrevista con Alfonso Gumucio Dagron, Signo y Pensamiento, 278-290.

Ramos, G. P. (2009). Psicología de la comunicación y difusión de valores. Salamanca: Publicaciones Universidad Pontificia de Salamanca.

Real Decreto 1420/1991, de 30 de agosto, por el que se establece el título universitario oficial de Diplomado en Educación Social y las directrices generales propias de los planes de estudios conducentes a la obtención de aquél. Boletín Oficial del Estado, 1991, núm. 243, pp. 32891.

Real Decreto 1393/2007, de 29 de octubre, por el que se establece la ordenación de las enseñanzas universitarias oficiales. Boletín Oficial del Estado, 30 de octubre de 2007, núm. 260, pp. 44037.

Real Decreto 861/2010, de 2 de julio, por el que se modifica el Real Decreto 1393/2007, de 29 de octubre, por el que se establece la ordenación de las enseñanzas universitarias oficiales. Boletín Oficial del Estado, 3 de julio de 2010, núm. 161, pp. 58454.

Resolución de 27 de junio de 2002, de la Universidad de Huelva, por la que se hace público el plan de estudios de Diplomado en Educación Social, a impartir en la Facultad de Ciencias de la Educación. Boletín Oficial del Estado, 2002, núm. 205, pp. 31641.

Rojas, A. D. (2010). Estudio sobre la asertividad y las habilidades sociales en el alumnado de Educación Social, XXI: Revista de Educación, 225-240.

Universidad de Huelva. (2012). Memoria verificada del título de Grado en Educación Social por la Universidad de Huelva. Available at <http:// www.uhu.es/fedu/apartados/Titulaciones/grado1213/Gra/EduS/ GraEduS1213memoria.pdf>. 